\title{
Production Economics and Profitability Analysis of Aquaculture in Southwest Bangladesh
}

\author{
Siddiqa $\mathrm{A}^{1 *}$, Shahroz $\mathrm{MH}^{2}$, Barman $\mathrm{BK}^{3}$, Ahmed $\mathrm{MU}^{4}$ and \\ Chakraborty $\mathrm{BK}^{1}$ \\ ${ }^{1}$ Department of Fisheries, Bangladesh \\ 2Bangladesh Agricultural University, Bangladesh \\ ${ }^{3}$ World Fish, Bangladesh and South Asia Office, Bangladesh \\ ${ }^{4}$ Solidaridad, Network Asia, Bangladesh
}

*Corresponding author: Ayesha Siddiqa, Department of Fisheries, Dhaka, Bangladesh, Tel: 008801715470855 ; Email: bborty@gmail.com

\begin{abstract}
Aquaculture provides suitable options for sustenance and income generation in Bangladesh. Southwest Bangladesh has a great potential for aquaculture development. Farmers in this region practice aquaculture in many patterns under three broad categories, such as commercial fish culture, commercial shrimp culture and homestead aquaculture. The study investigated the production economics and profitability of aquaculture practicing in southwest Bangladesh. The study shows aquaculture in southwest Bangladesh is feasible and profitable with a cost-benefit ratio of 1:1.71, 1:1.54, 1:1.30 for commercial fish culture, commercial shrimp culture and homestead aquaculture respectively. The per hectare total cost of production of commercial fish culture, commercial shrimp culture and homestead aquaculture are BDT 225615.46, 242860.17 and 185799.52 respectively and the corresponding total revenue are BDT 384767.00, 374662.62 and 242100.29. The per hectare net returns of commercial fish culture, commercial shrimp culture and homestead aquaculture are BDT 159151.54, 131802.45 and 56300.77 respectively. However, the farmers made the highest profit from commercial fish culture. The Cobb-Douglas production function analysis indicates that per hectare net returns are significantly influenced by input costs. These factors are directly or jointly responsible for influencing the per hectare net returns of all types of aquaculture. The sensitivity analysis shows that the variable costs including cost of fertilizers, fish feeds and fish seeds are the main factors affecting profitability.
\end{abstract}

Keywords: Aquaculture; Cost-Benefit Ratio (CBR); Cobb-Douglas Function; Production Economics; Southwest Bangladesh 


\section{International Journal of Oceanography \& Aquaculture}

Abbreviations: CBR: Cost Benefit Ratio; GDP: Gross Domestic Product; AIN: Aquaculture for Income and Nutrition; TC: Total Cost; TFC: Total Fixed Cost; TVC: Total variable Cost; TR: Total Revenue; NR: Net Return.

\section{Introduction}

Bangladesh has prospective culture fisheries resources and aquaculture plays a significant role for socio-economic development of Bangladesh. Aquaculture is important for both in terms of its contribution to the economy, as well as in the nutrition of people. It also creates a great opportunity of employment in Bangladesh. As capture fisheries are under considerable pressure and their production is either stagnant or declining, the supply of fish to meet the increased demand of overgrowing population can be sourced through aquaculture. About 15.51\% of GDP is derived from agriculture in fiscal year 2014-15 in which fisheries sector contributes $3.29 \%$ of total agricultural product [1] and aquaculture contributes about $55 \%$ of the total production of the country [2]. Overall, aquaculture plays an important role in the economy of Bangladesh, providing food, nutrition, incomes, livelihoods and export earnings [3-5]. Farmed fish is produced in Bangladesh through pond culture (homestead and commercial), seasonal floodplain aquaculture, rice-fish culture, cage culture, and gher culture (shrimp/prawn in coastal areas) [6]. The aquaculture practices in Bangladesh mostly followed traditional extensive and improved extensive with some semi-intensive polyculture of Indian major carps and exotic carps fish. Numerous projects have promoted simple improved management strategies, such as regular application of fertilizers and feeds, and the stocking of fish species in combinations and stocking densities designed to move the production system from extensive to semi-intensive [5].

Southwest region of Bangladesh are potential for both freshwater aquaculture and shrimp (Bagda and Golda) culture in brackish water. Shrimp culture is practiced for the farming of bagda (Penaeus monodon) together with carps, other white fish and golda (Macrobrachium rosenbergii). Freshwater aquaculture is practiced of carps as polyculture and carps with tilapia and golda both commercially and also traditionally in homestead. Homestead ponds in southwest Bangladesh are generally found to practice carp polyculture, carps with tilapia and Thai puti. The production scenarios of aquaculture of southwest Bangladesh are presented in following Table 1.

(Unit: Metric Ton)

\begin{tabular}{|c|c|c|c|c|c|c|}
\hline District & Pond (mt/ha) & $\begin{array}{c}\text { Seasonal cultured } \\
\text { water body }\end{array}$ & Baor & \multicolumn{2}{|c|}{ Shrimp/Prawn Farm Total } & Total \\
\hline & & & & Shrimp/Prawn (mt/ha) & Fish (mt/ha) & \\
\hline Khulna & $12379(2.99)$ & 0 & 160 & $25564(0.44)$ & $23492(0.40)$ & 82814 \\
\hline Bagerhat & $12277(2.48)$ & 8077 & 0 & $37794(0.52)$ & $19774(0.27)$ & 101626 \\
\hline Satkhira & $31701(2.14)$ & 8786 & 166 & $35264(0.46)$ & $23911(0.32)$ & 114278 \\
\hline Total & $56357(2.55)$ & 16863 & 326 & $98622(0.47)$ & $67177(0.33)$ & 298718 \\
\hline
\end{tabular}

(Source: FRSS 2016)

Table 1: Annual Total Fish Production in inland aquaculture in southwest Bangladesh.

The total fish production including shrimp obtained from inland aquaculture in Bangladesh is estimated at 2.41 million tons, of which about $10 \%$ has come from southwest Bangladesh; shrimp produced from this region contributes $78 \%$ of total shrimp production of the country [2]. Though fish and shrimp production in southwest Bangladesh has contributed significantly to the national economy but there is a lack of quantitative data about production economics at commercial and household levels. The study aimed at to assess the production economics of aquaculture in southwest region of Bangladesh with a view to finding out economic viability or profitability, correlation between the production variables and the total revenue and factors influencing profitability in the study area.

\section{Materials and Methods}

\section{Study Area}

The study was carried out in southwest region of Bangladesh. The region, comprising the districts of Satkhira, Khulna, Bagerhat and the southern part of Jessore possesses both freshwater and brackish water resources. The ecological and geological form of southwest Bangladesh is distinctive in many ways. The southwest region of Bangladesh, having tidal influence and sweet water supplies from upstream, has a unique brackish water ecosystem. It is a low, flat and fertile deltaic plan with calcareous to non-calcareous alluvial soils [7] and situated just behind the mangrove forest 


\section{International Journal of Oceanography \& Aquaculture}

Sundarban and Bay of Bengal. The population of the region is about 30 million with a total area of $40,500 \mathrm{sq}$ $\mathrm{km}$. Agriculture and fisheries are important economic sectors in the southwest Bangladesh, employing a large number of the population, and aquaculture is increasingly being practiced as an alternative livelihood option for rural households. The water of this region is slightly saline because of daily tidal fluctuation of riverine water which allows different types of fish culture practices, such as monoculture, polyculture, integrated culture, and crop rotation [8]. Khulna, Bagerhat and Satkhira districts were selected for this study from southwest Bangladesh, The study areas lie between $\mathrm{N} 22^{\circ} 39^{\prime}-22^{\circ} 50^{\prime}$ and E $89^{\circ} 32^{\prime}-89^{\circ}$ 45'.

\section{Data Collection}

For the purpose of data collection, a field survey was conducted at 160 villages of 9 upazila (Sub-administrative units) in Khulna, Bagerhat and Satkhira districts (Administrative units) from January to July 2015. It was based on primary data collected from randomly selected 450 aquaculture practicing households belonging to three categories of aquaculture like commercial fish culture, commercial shrimp culture and homestead aquaculture. The survey was conducted through pre-tested wellstructured questionnaire with the assistance of AIN (Aquaculture for Income and Nutrition) project of World Fish.

\section{Economic Analysis}

The cost of aquaculture was considered as the total of all fixed cost and variable cost. Total revenue was the multiplication of production and price of fish. We calculated the total income as of each individual fish species produced to the farm, including those for selfconsumption and distribution as gift. Economic performances as well as relative profitability of aquaculture were calculated on the basis of gross margin and net return analysis. Gross margin is difference between total revenue and total variable cost. Net return of aquaculture was calculated by subtracting the total cost (variable cost + fixed cost) from the total revenue obtained from aquaculture production. Cost-Benefit ratio is used to tell whether or not an investment will be profitable. Cost-Benefit Ratio (CBR) defined as a ratio of total cost to gross return. The following equations were used to analysis the production economics.

\section{Total cost $(\mathrm{TC})=$ Total Fixed cost $(\mathrm{TFC})+$ Total Variable cost (TVC)}

Total Revenue (Income) TR= Production $\mathrm{x}$ Price. Gross Margin $=$ TR - TVC
Net Return (NR) = TR-(TFC+TVC)

Cost-Benefit ratio (CBR) $=$ Total Cost $/$ Total Revenue.

Cost of equipment, pond excavation cost and lease value was measured as fixed cost. Cost of long term equipment like pump, net, drum etc. was calculated according to their life span or longevity and percentage of usage while actual price of short-term equipment was measured. Lease value of ponds and ghers (enclosure for shrimp culture) was estimated considering land used over a production period for one year. Similarly, cost of pond excavation was considered for one year.

Total variable cost was the summation of labour cost and all inputs cost of aquaculture production like seed cost, feed cost, fertilizer cost. The amount of money required to hire the labour was counted as labour cost. There were two types of labour found to be hired for commercial aquaculture, such as permanent labour and daily labour. Permanent labour was hired for the whole production cycle and paid monthly. Daily labour was hired according to need basis. In homestead aquaculture, daily labour was hired only for pond excavation and final harvesting.

In this study, Cobb-Douglas production function model was used to analysis the profitability of aquaculture. The model was applied to signify the effects of key variables on production process of aquaculture. According to Khai $\mathrm{HV}$, et al. [9], there are many functional forms for estimating the physical relationship between inputs and output, but the Cobb-Douglas functional form is preferred to other forms, especially if there are three or more independent variables in the model. The specification of Cobb-Douglas production functions as follows:

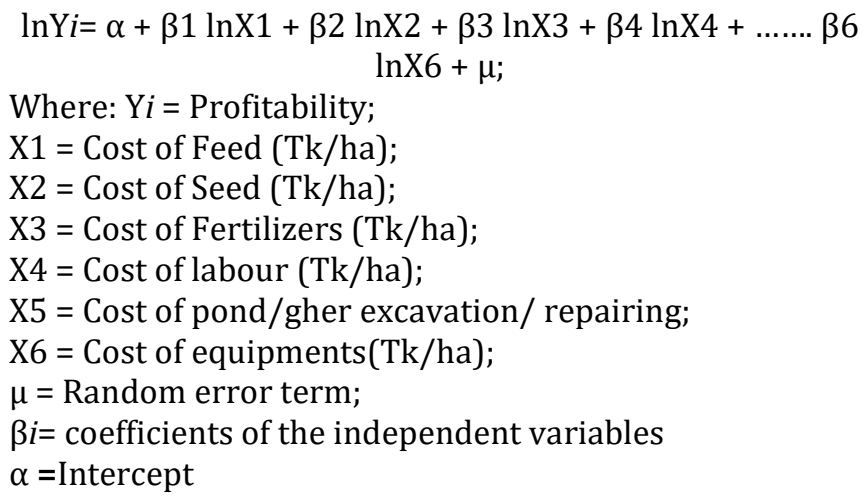

Sensitivity analysis is used in this study to determine how fluctuations in one variable can affect the profitability of the aquaculture. Sensitivity analysis is a set 


\section{International Journal of Oceanography \& Aquaculture}

of assumptions that can be used to examine the degree of uncertainty in a cost-benefit analysis.
The results of the total revenue, total cost, gross margin and net returns for all types of aquaculture in southwest Bangladesh are illustrated in Table 2.

\section{Results and Discussion}

\begin{tabular}{|c|c|c|c|c|c|c|c|c|c|}
\hline & $\begin{array}{c}\text { Commercial } \\
\text { Fish culture } \\
(n=150)\end{array}$ & & & $\begin{array}{c}\text { Commercial } \\
\text { Shrimp culture } \\
(n=150)\end{array}$ & & & $\begin{array}{c}\text { Homestead } \\
\text { aquaculture } \\
(n=150)\end{array}$ & & \\
\hline & $\begin{array}{c}\text { Value } \\
\text { (BDT/ha) }\end{array}$ & SD & $\begin{array}{c}\% \text { of } \\
\text { Total } \\
\text { Cost }\end{array}$ & Value (BDT/ha) & SD & $\begin{array}{c}\begin{array}{c}\% \text { of Total } \\
\text { Cost }\end{array} \\
\end{array}$ & $\begin{array}{c}\text { Value } \\
\text { (BDT/ha) }\end{array}$ & SD & $\begin{array}{l}\% \text { of } \\
\text { Total } \\
\text { Cost }\end{array}$ \\
\hline \begin{tabular}{|c|}
$\begin{array}{c}\text { Total Revenue } \\
\text { (TR) }\end{array}$ \\
\end{tabular} & 384767.00 & 131837.76 & & 374662.62 & 93659.22 & & 242100.29 & 70028.53 & \\
\hline \multicolumn{10}{|l|}{ Fixed cost } \\
\hline Excavation & 30379.80 & 21516.16 & 13.76 & 21798.29 & 15931.30 & 9.36 & 25633.81 & 16189.57 & 14.16 \\
\hline Equipment & 24071.90 & 22955.46 & 10.76 & 23527.35 & 17216.91 & 9.60 & 21160.39 & 15271.27 & 11.36 \\
\hline Lease value & 8752.790 & 27718.49 & 3.04 & 33532.65 & 43672.96 & 13.00 & 0.00 & 0.00 & 0.00 \\
\hline Total fixed cost & 63204.50 & 45877.73 & 27.55 & 78858.29 & 47224.39 & 31.96 & 46794.20 & 22372.33 & 25.52 \\
\hline \multicolumn{10}{|l|}{ Variable cost } \\
\hline Feed cost & 66936.52 & 41106.73 & 30.29 & 48722.61 & 33082.76 & 19.59 & 61615.49 & 23064.61 & 33.85 \\
\hline Seed cost & 65705.55 & 38020.63 & 29.52 & 92364.91 & 39700.70 & 38.67 & 55314.27 & 28569.95 & 29.34 \\
\hline Fertilizer cost & 8631.94 & 6579.59 & 4.12 & 6408.93 & 4791.57 & 2.72 & 6385.07 & 4637.26 & 3.49 \\
\hline Labor & 21136.94 & 24800.03 & 8.52 & 16505.44 & 16135.71 & 7.06 & 15690.49 & 18806.95 & 7.79 \\
\hline \begin{tabular}{|c}
$\begin{array}{c}\text { Total variable } \\
\text { cost }\end{array}$ \\
\end{tabular} & 162410.95 & 77052.41 & 72.45 & 164001.88 & 61467.49 & 68.04 & 139005.32 & 48526.79 & 74.48 \\
\hline Total cost $(A+B)$ & 225615.46 & 101003.48 & 100.00 & 242860.17 & 78405.48 & 100.00 & 185799.52 & 56687.02 & 100.00 \\
\hline $\begin{array}{c}\text { Total } \\
\text { Production } \\
\text { (kg/ha) }\end{array}$ & 2469.78 & 719.37 & & 1158.37 & 445.09 & & 1591.66 & 349.27 & \\
\hline Fish (kg/ha) & 2343.44 & & & 726.8 & & & 1525.84 & & \\
\hline Shrimp (kg/ha) & 126.34 & & & 431.57 & & & 65.82 & & \\
\hline Net return & 159151.54 & 110826.03 & & 131802.45 & 86392.79 & & 56300.77 & 43519.69 & \\
\hline \begin{tabular}{|l|} 
Gross margin \\
\end{tabular} & 222356.05 & 103763.52 & & 210660.74 & 80691.86 & & 103094.98 & 42767.91 & \\
\hline CBR & $1: 1.07$ & 1.08 & & $1: 1.54$ & 0.65 & & $1: 1.30$ & 0.29 & \\
\hline
\end{tabular}

Source: Field Survey, 2015.

Table 2: Analysis of cost and returns of aquaculture in southwest Bangladesh.

\section{Total Production}

Most of the farmers in the southwest region practice all types of aquaculture through stocking both fish species and shrimp species in their ponds and ghers. The stocking ratio and production of fish and shrimp were observed to vary depending on the culture type. The average per hectare production of fish and shrimp was $2343.44 \mathrm{~kg}$ and $126.34 \mathrm{~kg}$ in commercial fish farms while $726.80 \mathrm{Kg}$ fish and $431.57 \mathrm{~kg}$ shrimp were harvested from commercial shrimp farms.

In the district of Khulna, Bagerhat and Satkhira, the total fish production of pond was $2.55 \mathrm{mt} / \mathrm{ha}$ while 0.47 $\mathrm{mt}$ shrimp and $0.33 \mathrm{mt}$ fish were produced from shrimp farms [2]. These productions are more or less similar to the study results of fish production from commercial fish farms and shrimp production from commercial shrimp farms. The fish and shrimp production of homestead ponds were $1525.84 \mathrm{~kg} / \mathrm{ha}$ and $65.82 \mathrm{~kg} / \mathrm{ha}$ respectively.

\section{Total Revenue}

The results of the study indicate that the per hectare average total revenue were BDT 384767.00 in commercial fish culture, 374662.62 in commercial shrimp culture and 242100.29 in homestead aquaculture. Total revenue was calculated by the multiplication of species wise farm production of fish and shrimp and the actual price obtained by farmers. The average annual gross 


\section{International Journal of Oceanography \& Aquaculture}

revenue of fish farming was estimated at BDT 238640.00 per hectare, varying from BDT 121360.00 in extensive farming to BDT 224720.00 in semi-intensive and BDT 369760 in intensive farming in Mymensingh district [10].

\section{Total Cost}

In this study, per hectare total cost of production of commercial fish culture, commercial shrimp culture and homestead aquaculture were BDT 225615.46, 242860.17 and, 185799.52 respectively.

\section{Fixed Cost}

Total fixed cost for aquaculture production were BDT $63204.50,78858.29$ and 46794.20 per hectare which shared $27.55 \%, 31.96 \%$ and $25.52 \%$ correspondingly of total cost of commercial fish culture, commercial shrimp culture and homestead aquaculture. Total fixed cost was higher in commercial fish and shrimp culture than those in homestead aquaculture because homestead ponds had no lease value.

\section{Variable Cost}

From this study it was observed that total variable cost were BDT $162410.95,164001.88$ and 139005.32 per hectare in commercial fish, shrimp and homestead aquaculture respectively. Variable cost constituted $72.45 \%$ of total cost for commercial fish culture, $68.04 \%$ for commercial shrimp culture and $74.48 \%$ for homestead aquaculture. Mondal MAH, et al. [10] reported that, the per hectare average annual variable costs and fixed costs of aquaculture in Mymensingh district constituted 79\% and $21 \%$ respectively of total cost.

\section{Gross Margin and Net Returns}

The per hectare gross margin was estimated as BDT $222356.05,210660.74$ and 103094.98 for commercial fish culture, commercial shrimp culture and homestead aquaculture respectively and the corresponding net returns were BDT 159151.54, 131802.45 and 56300.77. There was a considerable difference in income between commercial and homestead aquaculture.

\section{Cost-Benefit Ratio and Profitability}

The profitability analysis shows that in cost-benefit ratios of commercial and homestead aquaculture benefits were greater than one. The results indicate that all types of aquaculture in southwest Bangladesh were profitable. However commercial fish culture, commercial shrimp culture and homestead aquaculture being practiced in southwest Bangladesh is feasible and profitable with a cost-benefit ratios of 1:1.71, 1:1.54, and 1:1.30 respectively Table 2. Mohsin ABM, et al. [11] estimated CBR of 1:1.05 in carp polyculture practiced in Rajshahi and Natore districts of Bangladesh while Islam $\mathrm{M}$, et al. [12] recorded CBR of 1:2.73 in case of carp growout ponds in Rajshahi district (Table 3).

\begin{tabular}{|c|c|c|c|c|}
\hline Items & Mean & Minimum & Maximum & SD \\
\hline Commercial fish culture & & & & \\
\hline Total Revenue (BDT/ha) & 384767.00 & 134306.25 & 792870.00 & 131837.76 \\
\hline Total Cost (BDT/ha) & 225615.46 & 43175.60 & 701538.81 & 101003.48 \\
\hline Gross Margin (BDT/ha) & 222356.05 & 36144.33 & 553203.61 & 103763.52 \\
\hline Net Returns (BDT/ha) & 159151.54 & -6092.67 & 541681.19 & 110826.03 \\
\hline Profitability & 0.71 & 0.00 & 0.77 & \\
\hline Commercial shrimp culture & & & & \\
\hline Total Revenue (BDT/ha) & 374662.62 & 154375.00 & 711060.61 & 93659.22 \\
\hline Total Cost (BDT/ha) & 242860.17 & 58969.88 & 516087.79 & 78405.48 \\
\hline Gross Margin (BDT/ha) & 210660.74 & 50644.88 & 461283.73 & 80691.86 \\
\hline Net Returns (BDT/ha) & 131802.45 & -26406.55 & 378180.99 & 86392.79 \\
\hline Profitability & 0.54 & 0.00 & 0.73 & \\
\hline Homestead aquaculture & & & & \\
\hline Total Revenue (BDT/ha) & 242100.29 & 88540 & 484737.5 & 70028.53 \\
\hline Total Cost (BDT/ha) & 185799.5 & 76021.11 & 338217.1 & 56687.02 \\
\hline Gross Margin (BDT/ha) & 103095 & -33493.2 & 239590 & 42767.91 \\
\hline Net Returns (BDT/ha) & 56300.77 & -92081.6 & 169040.63 & 43519.69 \\
\hline Profitability & 0.3 & 0 & 0.71 & \\
\hline
\end{tabular}

Source: Field Survey, 2015.

Table3: Profitability of commercial and homestead aquaculture in southwest Bangladesh $(n=450)$. 
Table 3 shows the range of total revenue, total cost, gross margin, net returns and profitability of selected commercial and homestead aquaculture farms with maximum value and standard deviation. Profitability refers to net returns as compared to the cost of production.

According to the results of net returns, profitability ranged from 0 to 0.77 in commercial fish culture, 0-0.73 in commercial fish culture and 0-0.71 in homestead aquaculture respectively. This table also shows that minimum value of net returns of all types of aquaculture were negative indicating some fish and shrimp farms under both commercial and homestead categories were not profitable.

\section{Factors Affecting Net Returns of Aquaculture Production}

The Cobb-Douglas production function is used to identify the factors that affect profitability of aquaculture production on the basis of significant effects of input cost on net returns. The factors that affect the profitability of commercial fish culture, commercial shrimp culture and homestead aquaculture are presented in Table 4.

\begin{tabular}{|c|c|c|c|c|}
\hline Variables & Coefficient & Std.Error & t-Value & p-Value \\
\hline \multicolumn{5}{|l|}{ Commercial fish culture } \\
\hline (Constant) & 226723.66 & 21531.11 & 10.53 & 0 \\
\hline Equipments cost (BDT/ha) & -0.953 & 0.437 & -2.18 & 0.031 \\
\hline Excavation cost (BDT/ha) & -1.277 & 0.482 & -2.651 & 0.009 \\
\hline Lease Value (BDT/ha) & -0.215 & 0.313 & -0.687 & 0.493 \\
\hline Fertilizer Cost (BDT/ha) & -2.546 & 1.35 & -1.886 & 0.061 \\
\hline Feed Cost (BDT/ha) & 0.011 & 0.225 & 0.049 & 0.961 \\
\hline Seed Cost (BDT/ha) & 0.172 & 0.26 & 0.66 & 0.51 \\
\hline Labour Cost (BDT/ha) & 0.284 & 0.353 & 0.805 & 0.422 \\
\hline \multicolumn{5}{|l|}{ Commercial shrimp culture } \\
\hline (Constant) & 219412.266 & 21074.33 & 10.411 & 0 \\
\hline Equipments cost (BDT/ha) & 0.294 & 0.39 & 0.753 & 0.453 \\
\hline Excavation cost (BDT/ha) & -1.424 & 0.405 & -3.513 & 0.001 \\
\hline Lease Value (BDT/ha) & -0.864 & 0.148 & -5.821 & 0 \\
\hline Fertilizer Cost (BDT/ha) & 0.214 & 1.382 & 0.154 & 0.877 \\
\hline Feed Cost (BDT/ha) & -0.725 & 0.207 & -3.497 & 0.001 \\
\hline Seed Cost (BDT/ha) & -0.07 & 0.172 & -0.408 & 0.684 \\
\hline Labour Cost (BDT/ha) & 0.357 & 0.399 & 0.894 & 0.373 \\
\hline \multicolumn{5}{|l|}{ Homestead aquaculture } \\
\hline (Constant) & 69814.494 & 12656.875 & 5.516 & 0 \\
\hline Equipments cost (BDT/ha) & -0.456 & 0.232 & -1.963 & 0.052 \\
\hline Excavation cost (BDT/ha) & -0.711 & 0.215 & -3.302 & 0.001 \\
\hline Fertilizer Cost (BDT/ha) & 0.781 & 0.814 & 0.959 & 0.339 \\
\hline Feed Cost (BDT/ha) & 0.004 & 0.154 & 0.025 & 0.98 \\
\hline Seed Cost (BDT/ha) & 0.02 & 0.13 & 0.15 & 0.881 \\
\hline Labour Cost (BDT/ha) & 0.376 & 0.189 & 1.985 & 0.049 \\
\hline a. Dependent Variable: Net Returns (BDT/ha) & & & & \\
\hline
\end{tabular}

Source: Field Survey, 2015

Table 4: Factors affecting the profitability of aquaculture in south west Bangladesh.

For all the three types of aquaculture, seven variables are considered to describe the effects of fixed and operational variables in net returns. The coefficients for fixed cost in all aquaculture are negative, so for every 
unit decrease in fixed cost of aquaculture, a unit increase in net returns is expected, remaining variable cost constant except equipment cost in commercial shrimp culture having positive coefficients. Further, it is observed from the Cobb-Douglas production function that the production coefficient of labour cost of all types of aquaculture is significant holding positive value. The coefficient for fertilizer cost in commercial fish culture is 2.546 indicating a unit decrease in fertilizer cost would increase the net returns from commercial fish farms. Similarly coefficient for feed cost and seed cost $(-0.725$ and -0.070 respectively) in commercial shrimp culture shows a unit decrease in feed cost and feed cost would increase the net returns from shrimp culture. Commercial shrimp culture and homestead aquaculture have the positive coefficients for fertilizer cost and whereas commercial fish culture and homestead aquaculture hold positive value of coefficients for feed cost and seed cost (Table 4).

\section{Sensitivity Analysis}

The profitability analysis showed that all types of aquaculture are profitable in the study area but it is necessary to define their sustainability. Every project may have some uncertainties that affect the profit margin of that project. Similarly, the uncertainties may affect the profitability of aquaculture farms. Considering the facts, sensitivity analysis was conducted in this study. Sensitivity analysis is a technique used to assess how different values of an independent variable will influence a particular dependent variable under a given set of assumptions. Sensitivity analysis is the study of how the variation (uncertainty) in the output of a mathematical model can be apportioned to different sources of variation in the inputs of a mode [13].

Commercial fish culture is still profitable even if all the variable costs are increased by $20 \%$ remaining the revenue fixed though profit margin is lower than the original value. The profitability of commercial fish culture largely varies with the decrease in fish price and increase in feed and seed cost. If aquaculture production of commercial fish culture is increased by $5 \%$ to $10 \%$ and others remain constant or if variable cost is increased by $10 \%$ the profit margin is increased by $6 \%$ to $4 \%$ from the original profit margin. On the other hand, even price of fish is decreased by $30 \%$, the commercial fish farmers can enjoy $25 \%$ profit if they can produce $5 \%$ more fish. Similarly farmers can also make profit with feed cost and seed cost increase by $10 \%$ (Table 5 ).

\begin{tabular}{|c|c|c|c|c|c|}
\hline S.No & Scenario & $\begin{array}{c}\text { Total } \\
\text { revenue }\end{array}$ & $\begin{array}{c}\text { Total } \\
\text { variable }\end{array}$ & $\begin{array}{c}\text { Net Return } \\
\text { (Profit) }\end{array}$ & $\begin{array}{c}\text { Profit } \\
\text { margin } \\
\text { (\%) }\end{array}$ \\
\hline & Original mean value (BDT/ha) & 384767 & 162410.95 & 159151.54 & 71 \\
\hline 1 & All variable cost increase by 20\% without revenue change & 384767 & 194893.14 & 126669.36 & 49 \\
\hline 2 & Production increase by 5\% and others remain constant & 404005.35 & 162410.95 & 178389.9 & 79 \\
\hline 3 & Production increase by10\% and variable cost increase by 10\% & 423243.7 & 178652.045 & 181387.16 & 75 \\
\hline 4 & $\begin{array}{c}\text { Feed cost and seed cost increase by 10\% and others remain } \\
\text { constant }\end{array}$ & 384767 & 175675.16 & 145887.34 & 61 \\
\hline 5 & Price decrease by 30\% and Production increases by 5\% & 282803.75 & 162410.95 & 57188.295 & 25 \\
\hline
\end{tabular}

Source: Authors calculation based on field survey.

Table 5: Sensitivity analysis of commercial fish culture production (n-150).

The profitability of commercial shrimp culture is mostly sensitive to both the decrease in the price of shrimp and increase in feed cost. Profit margin of commercial shrimp farms may decrease from $54 \%$ to $36 \%$ if all the variable cost is increased by $20 \%$ while shrimp production is increased by only $5 \%$ remaining other input cost constant, the shrimp farmers can enjoy an increased amount (60\%) of profit. Therefore, if the

\begin{tabular}{|c|c|c|c|c|c|}
\hline $\begin{array}{c}\text { S.N } \\
0\end{array}$ & Scenario & $\begin{array}{c}\text { Total } \\
\text { revenue }\end{array}$ & $\begin{array}{c}\text { Total } \\
\text { variable }\end{array}$ & $\begin{array}{l}\text { Net Return } \\
\text { (Profit) }\end{array}$ & $\begin{array}{c}\text { Profit margin } \\
\text { (\%) }\end{array}$ \\
\hline
\end{tabular}

total variable cost is increased by $10 \%$, and the farmers produce $10 \%$ more shrimp, can get more or less same amount of profit as original profit value. Similarly, if the price of shrimp is decreased by $40 \%$, the commercial shrimp farmers can get $14 \%$ profit if they can produce $5 \%$ more shrimp. In addition, farmers can also earn more profit with $10 \%$ decreased of seed cost (Table 6).

Southwest Bangladesh. Int J Oceanogr Aquac 2018, 2(6): 000156.
Copyright@ Siddiqa A, et al. 


\section{International Journal of Oceanography \& Aquaculture}

\begin{tabular}{|l|c|c|c|c|c|} 
& Original mean value (BDT) & 374662.62 & 164001.88 & 131802.45 & 54 \\
\hline 1 & All variable cost increase by 20\% without revenue change & 374662.62 & 196802.256 & 99002.074 & 36 \\
\hline 2 & $\begin{array}{c}\text { Shrimp production increase by 5\% and other input cost } \\
\text { remain constant }\end{array}$ & 387915.06 & 164001.88 & 145054.8858 & 60 \\
\hline 3 & $\begin{array}{c}\text { Shrimp production increase by 10\% and other input cost } \\
\text { increase by 10\% }\end{array}$ & 401167.49 & 180402.068 & 141907.1336 & 55 \\
\hline 4 & Seed cost decrease by 10\% and others remain constant & 374662.62 & 154765.4 & 141038.931 & 60 \\
\hline 5 & Price decrease by 40\% and Production increases by 5\% & 276594.6 & 164001.88 & 33734.42527 & 14 \\
\hline
\end{tabular}

Source: Authors calculation based on field survey.

Table 6: Sensitivity analysis of commercial shrimp culture production (n-150).

The aquaculture production of homestead ponds is also profitable with a number of scenarios except in the scenario related to price of fish. Production increase by $5 \%$ to $10 \%$ with constant input cost and $10 \%$ increased of all input cost correspondingly can contribute $37 \%$ and $33 \%$ profit to the farmers. If both feed and seed cost is decreased by $10 \%$ keeping others constant can provide $39 \%$ profit while increase in all input cost by $10 \%$ can make the profit lower than the original profit. If the prices of fish falls by up to $30 \%$ remaining other variables constant, the production of homestead aquaculture in the study area would not be profitable (Table 7).

\begin{tabular}{|c|c|c|c|c|c|}
\hline S.No & Scenario & $\begin{array}{c}\text { Total } \\
\text { revenue }\end{array}$ & $\begin{array}{c}\text { Total } \\
\text { variable }\end{array}$ & $\begin{array}{c}\text { Net Return } \\
\text { (Profit) }\end{array}$ & $\begin{array}{c}\text { Profit margin } \\
\text { (\%) }\end{array}$ \\
\hline & Original mean value (BDT) & 242100.29 & 139005.32 & 56300.77 & 30 \\
\hline 1 & All input cost increase by 20\% without revenue change & 242100.29 & 166806.38 & 28499.71 & 13 \\
\hline 2 & $\begin{array}{c}\text { Production increase by 5\% and other input cost remain } \\
\text { constant }\end{array}$ & 254205.3 & 139005.32 & 68405.78 & 37 \\
\hline 3 & $\begin{array}{c}\text { Production increase by10\% and other input cost increase } \\
\text { by 10\% }\end{array}$ & 266310.32 & 152905.85 & 66610.27 & 33 \\
\hline 4 & $\begin{array}{c}\text { Feed and seed cost decrease by 10\% and others remain } \\
\text { constant }\end{array}$ & 242100.29 & 127312.34 & 67993.75 & 39 \\
\hline 5 & Price decrease by 30\% and others remain constant & 169470.2 & 139005.32 & -16329.32 & 0 \\
\hline
\end{tabular}

Source: Authors calculation based on field survey.

Table 7: Sensitivity analysis of homestead aquaculture production (n-150).

\section{Conclusion}

It is concluded that the fish farmers in the southwest Bangladesh can obtain positive net returns with $\mathrm{BC}$ ratios greater than 1 from all types of aquaculture. In the context of income generation and poverty alleviation, commercial aquaculture practices may play a key role in meeting the cash needs of the farmers while homestead aquaculture may provide family nutrition. Apart from this, all types of aquaculture have potential scope for rural women to be involved in an income generating activity. The study shows that total revenue, net returns and $\mathrm{BC}$ ratio for commercial fish culture, commercial shrimp culture and homestead aquaculture are relatively comprehensive from an economic perspective. It is also to mention that commercial fish farmers in the study area faced problems of quality fish seeds and feeds whereas, in homestead aquaculture, feed application was not rational. For sustainable growth in aquaculture production and profitability improvements, some recommendations have been made: fish farmers should re-arrange the usage of inputs rationally so that they can make the least-cost input combination. Farmers also should record the all accounts of their operation costs through adopting the use of record books for genuinely computing the aquaculture profitability and the sensitivity of farms. In addition, proper government monitoring can ensure the availability of quality fish seed and fish feed in the study area. Both government and non-government extension agencies also should provide need based training with cost effective aquaculture technologies so that the farmers can make their right way in aquaculture production. 


\section{International Journal of Oceanography \& Aquaculture}

\section{References}

1. BBS (2014) Statistical Yearbook of Bangladesh, Bangladesh Bureau of Statistics, Statistical Division, Ministry of Planning, Government of the People's Republic of Bangladesh, Dhaka.

2. FRSS (2016) Fisheries Statistical Report of Bangladesh. Fisheries Resources Survey System (FRSS), Department of Fisheries, Bangladesh 32: 57.

3. Dey MM, Alam MF, Bose ML (2010) Demand for aquaculture development: perspectives from Bangladesh for improved planning. Reviews in Aquaculture 2(1): 16-32.

4. Jahan KM, Ahmed M, Belton B (2010) The impacts of aquaculture development on food security: lessons from Bangladesh. Aquaculture Research 41(4): 481495.

5. Belton B, Karim M, Thilsted S, E-Jahan KM, Collis W, et al. (2011) Review of aquaculture and fish consumption in Bangladesh. Studies and Reviews 2011-53, The WorldFish Center 1-71.

6. Apu AN (2014) Bangladesh small and medium-scale aquaculture value chain development: Past trends, current status and likely future directions. Nairobi, Kenya: ILRI: 1-117.

7. BBS (2004) Statistical Yearbook of Bangladesh, Bangladesh Bureau of Statistics, Statistical Division, Ministry of Planning, Government of the People's Republic of Bangladesh, Dhaka.
8. Roy AK, Ghosh AK, Arafat ST, Huq KA (2013) Fishpaddy crop rotation practice in south- west coastal region of Bangladesh: a profitable technology for the poor farmers. Bangladesh Journal of Agricultural Research 38(3): 389-399.

9. Khai HV, Yabe M (2011) Technical efficiency analysis of rice production in Vietnam. Journal of ISSAAS 17(1): 135-146.

10. Mondal MAH, Ali MM, Sarma PK, Alam MK (2012) Assessment of aquaculture as a means of sustainable livelihood development in Fulpur upazila under Mymensingh district. Journal of the Bangladesh Agricultural University 10(2): 391-402.

11. Mohsin ABM, Islam MN, Hossain MA, Galib SM (2012) Cost-benefit analyses of carp polyculture in ponds: a survey study in Rajshahi and Natore districts of Bangladesh. Bangladesh Journal of Environmental Science 23: 103-107.

12. Islam M, Haque NE, Mohsin ABM (2008) Carp culture: Cost-return and profit analysis of Rajshahi district, Bangladesh. Journal of Fisheries International 3(3): 52-55.

13. Saltelli A, Ratto M, Andres T, Campolongo F, Cariboni J, et al. (2008) Global Sensitivity Analysis. The Primer, John Wiley \& Sons Ltd 1-292.

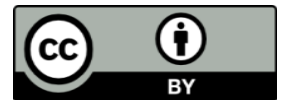

